\title{
The effects of diets with no fat or with hydrogenated or unhydrogenated fat on growth and tissue pathology of rats
}

\author{
By J. P. FUNCH, A. JART AND H. DAM \\ The Danish Fat Research Institute, Copenhagen \\ (Received 6 fune 1959-Revised I4 October 1959)
}

It has been demonstrated (Funch, Aaes-Jørgensen \& Dam, 1957) that hydrogenated arachis oil, compared with trilaurin, increased the rat's requirement for essential fatty acids, and in the absence of essential fatty acids aggravated the deficiency signs caused by inadequate supplies of them. The noxious effect of hydrogenated arachis oil was completely prevented by $100 \mathrm{mg}$ ethyl linoleate/rat/day. It was suggested that the difference in effect on rats of high dietary levels of trilaurin and hydrogenated arachis oil might be explained by assuming that increased amounts of long-chain dietary fatty acids increase the requirement for essential fatty acids more than do increased amounts of medium-chain acids. It was also suggested that the deleterious effect of hydrogenated arachis oil might be due partly to the presence of isomers of the unsaturated fatty acids formed during hydrogenation.

The purpose of the experiments reported here was to investigate the latter possibility further by comparing the effect of partly hydrogenated coconut oil with that of completely hydrogenated coconut oil when fed to weanling rats for a period of 16 weeks. In partly hydrogenated coconut oil isomers of unsaturated fatty acids formed during hydrogenation may be present, but the addition to the diet of completely saturated coconut oil eliminates the chance of giving isomers of unsaturated fatty acids.

\section{EXPERIMENTAL}

Two series of experiments are reported here because in Expt I, with thirteen groups each of six animals, some growth differences were on the borderline of significance. Expt 2, with twenty groups of twelve rats each, was designed as an extension and repetition of Expt x. Newly weaned rats, three in each cage, were used in both experiments. Percentage compositions of the diets and their calorie contents are shown in Table $\mathbf{I}$. The composition of every diet was adjusted so that all contained the same amounts of casein, salts, vitamin mixture and choline chloride per calorie unit. In Expt I vitamins $A$ and $D_{2}$ were given as drops of an aqueous colloidal solution (Decamin aquosum, Ferrosan Ltd, Copenhagen), supplying 120 i.u. vitamin $A$ and 18 i.u. vitamin $\mathrm{D}_{2} /$ rat/week. In Expt 2, vitamins $\mathrm{A}$ and $\mathrm{D}_{3}$ were supplied as a stabilized powder (Rovimix $A+D_{3}$, Type 50/5, Roche Products $L t d$ ), to give in each $10 \mathrm{~g}$ of food r 50 i.u. vitamin $A$ and 15 i.u. vitamin $\mathrm{D}_{3}$. 
The chemical and physical properties of the fats used are listed in Table 2. The conditions of hydrogenation of coconut oil are set out below.

For partial or complete hydrogenation of coconut oil the catalyst was nickel $(0.25 \%$ by weight of the oil). Partial hydrogenation was performed at $150^{\circ}$ for $5 \mathrm{~min}$ at $2 \mathrm{~atm}$ of hydrogen pressure. Complete hydrogenation was accomplished at $200^{\circ}$ for 30 min at II atm of hydrogen pressure.

\section{Table I. Percentage composition and calorie content (kcal/g) of the diets}

\begin{tabular}{|c|c|c|c|c|c|c|}
\hline $\begin{array}{l}\text { Vitamin Test } \\
\text { Casein }\end{array}$ & Sucrose & Fat $†$ & $\begin{array}{c}\text { Salt } \\
\text { mixturet }\end{array}$ & $\begin{array}{l}\text { Vitamin } \\
\text { mixture§ }\end{array}$ & $\begin{array}{l}\text { Choline } \\
\text { chloride }\end{array}$ & Calories \\
\hline 20 & 74 & 0 & 5 & 0.50 & 0.50 & $3 \cdot 76$ \\
\hline $21 \cdot 8$ & $64 \cdot 6$ & 7 & $5 \cdot 5$ & 0.55 & 0.55 & 4.09 \\
\hline $27^{\circ} 0$ & $37^{\circ} 0$ & 28 & 6.7 & 0.65 & 0.65 & 5.08 \\
\hline $\begin{array}{l}\text { - Genatosan } \\
\dagger \text { For comp } \\
\ddagger \text { See Funcl } \\
\S 500 \mathrm{~g} \text { vitan } \\
\text { acid } 35 \mathrm{~g} \text {, thia } \\
\text { thenate } 5 \mathrm{~g}, \mathrm{n} \\
\text { Roche Product } \\
\text { ester (Synkavit } \\
\text { tained, in addit } \\
\text { added to mixt } \\
\text { at the expense }\end{array}$ & $\begin{array}{l}\text { Ltd, Lou } \\
\text { sition see } \\
\text { Nielsen } \\
\text { in mixtur } \\
\text { nine hydr } \\
\text { cotinic ac } \\
\text { std) } 58 \\
\text { Roche Pr } \\
\text { ion to the } \\
\text { re no. I a }\end{array}$ & $\begin{array}{l}\text { rough } \\
\text { le } 2 \text {. } \\
\text { am (Id } \\
\text { I for } \\
\text { oride } \\
\text { g, ino } \\
\text {-calciu } \\
\text { cts Ltt } \\
\text { nins o } \\
g \text { of a }\end{array}$ & $\begin{array}{l}\text { land. } \\
\text { I containe } \\
\text { boflavin } 5 \\
\text { I } 5 \mathrm{~g} \text {, asco } \\
\text { of } 2 \text {-me } \\
\text { and sucros } \\
\text { ure no. I, } \\
\text { powder ( }\end{array}$ & $\begin{array}{l}\text { otin } 50 \mathrm{mg} \\
\text { yridoxine } \\
\text { acid } 5 \mathrm{~g}, \\
4-\text {-naphth } \\
\text { g. Vit: } \\
000 \text { i.u. vit } \\
\text { nix } A+D_{3}\end{array}$ & $\begin{array}{l}\text { acid } 50 \mathrm{n} \\
\text { chloride } \\
\text { ocophery } \\
\text { oquinone } \\
\text { nixture nc } \\
\text { A and } 150 \\
\text { e } 50 / 5, \mathrm{R}\end{array}$ & $\begin{array}{l}\text { aminoben } \\
\text { lcium par } \\
\text { te (Ephy } \\
\text { sphoric } \\
\text { Expt } 2 \\
\text { u. vitamir } \\
\text { roducts I }\end{array}$ \\
\hline
\end{tabular}

After hydrogenation, which was carried out with vigorous stirring, the catalyst was removed by filtration. The oils were treated at $75^{\circ}$ with a $15 \%(\mathrm{w} / \mathrm{v})$ solution of sodium hydroxide, and after 15 min the sodium hydroxide was removed with a 10 $\%(\mathrm{w} / \mathrm{v})$ solution of sodium chloride. The last traces of water and soap were removed by treatment with kieselguhr for $20 \mathrm{~min}$. After filtration, the fats were deodorized with $20 \%$ steam (weight of steam to weight of oil) for $3 \mathrm{~h}$ at $160-163^{\circ}$ and a pressure of $20-25 \mathrm{~mm}$ of mercury.

The rats were fed ad lib. and food consumption was measured daily during the first Io weeks of experiment. The calorie intake/rat/day and the efficiency of utilization of calories for growth during the same period were calculated. The animals were weighed and inspected weekly and were killed with ether at the end of the experiments, which lasted I 6 weeks. Autopsies were performed. In Expt 2, samples of depot fat were collected from the animals fed on $28 \%$ partly or completely hydrogenated coconut oil or on coconut oil. The samples from each group were pooled for estimation by infrared analysis of trans fatty acids calculated as elaidic acid (Jart, 1960). From all the animals material was collected for histological examination.

Blocks of tissue were fixed in $10 \%$ commercial formalin (corresponding to $4 \%$ $(w / v)$ formaldehyde). Paraffin sections were stained with haematoxylin and eosin. Material from all the livers was cut on a freezing microtome and stained for lipids with Sudan black. 
Vol. I4

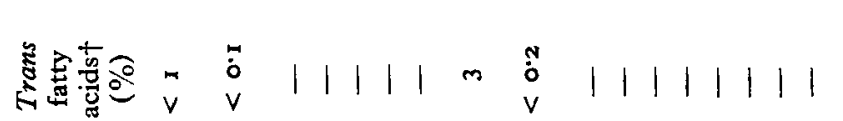

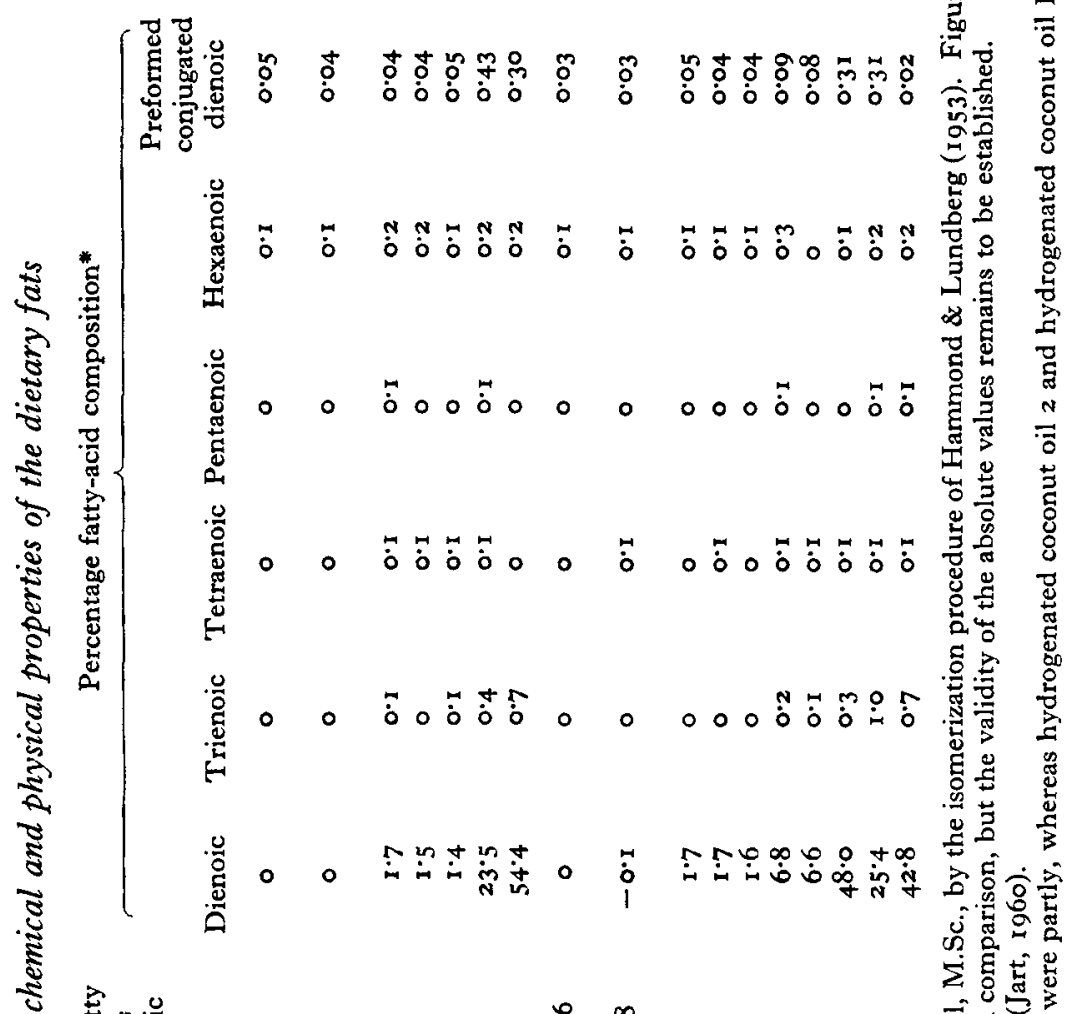

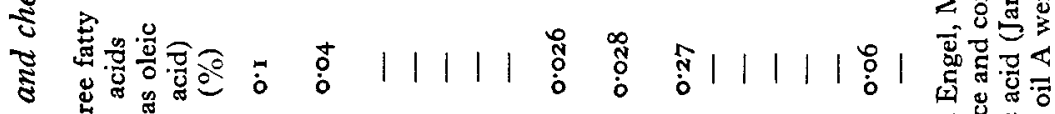

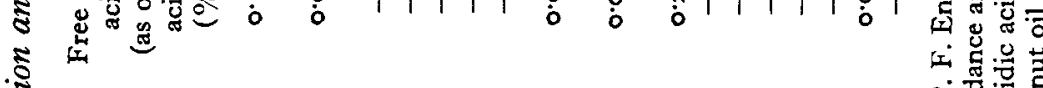

密

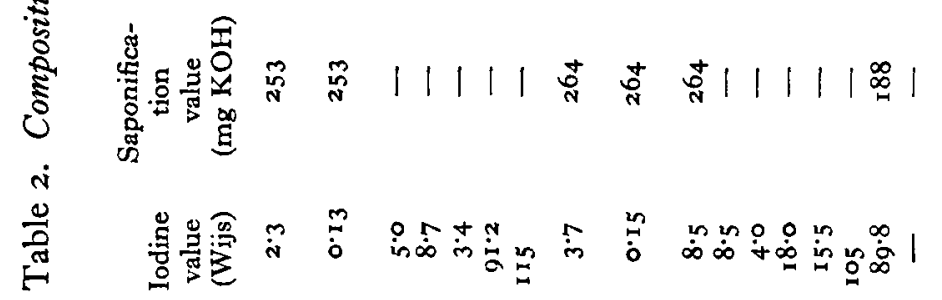

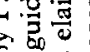

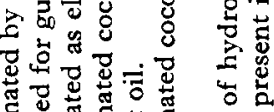

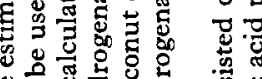

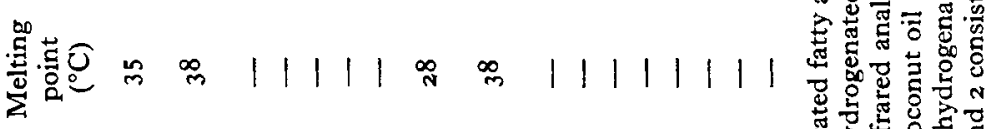

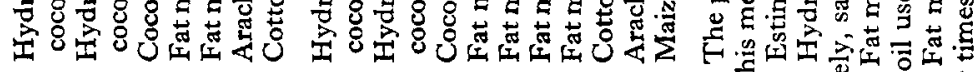
葍宫

- 


\section{RESULTS}

\section{Growth rate}

In Table 3 are listed the numbers of rats and mean weights of each group after experimental periods of 10 and 16 weeks, as well as calorie intakes and efficiencies of utilization of calories for growth during the first 10 weeks of experiment. It will be seen that the rats fed on partly hydrogenated coconut oil as the sole dietary fat (groups 21 and 22 in Expt $I$ and groups 43 and 56 in Expt 2) did not grow more slowly or less efficiently than those fed on corresponding amounts of completely hydrogenated coconut oil (groups 23 and 24 in Expt 1 and groups 44 and 57 in Expt 2). In fact, partly hydrogenated coconut oil appeared sometimes to be superior to completely hydrogenated coconut oil, but the differences were not statistically significant $(P>0 \cdot I)$. The growth rates of the rats on fat-free diets (groups 20,42) were not significantly different from those obtained on diets with $28 \%$ partly or completely hydrogenated coconut oil. In Expt 2, however, the growth rates on diets with $7 \%$ hydrogenated coconut oil were nearly significantly better than that on the fat-free diet. The $7 \%$ dietary levels of hydrogenated coconut oil consistently gave somewhat better growth than the $28 \%$ levels of the same fats. The rats fed on partly or completely hydrogenated coconut oil grew significantly less well $(P<0.05$ after Io weeks and $P<0.0$ I after 16 weeks) and utilized the calories consumed less efficiently than those fed on coconut oil (groups 25 and 26 in Expt 1 and groups 45 and 58 in Expt 2).

In Expt I, rats given partly hydrogenated coconut oil supplemented with cottonseed oil (fat mixture I, groups 27 and 28 ), so that the linoleic-acid content of the mixture (based on isomerization analysis) was equal to that of coconut oil, had growth rates and efficiency constants almost equal to those obtained on the corresponding coconut-oil diets (groups 25 and 26). Supplementation of completely hydrogenated coconut oil by cottonseed oil (fat mixture 2, groups 29 and 30 ) did not appear in Expt I to ensure growth and efficiency constants equal to those obtained on the coconut oil diets. The differences in weight increase, however, were not significant $(P>0 . \mathrm{I})$ for the $7 \%$ dietary level and significant only at a low level of probability $(P>0.02)$ for the $28 \%$ dietary level. In Expt 2 supplementation of partly as well as completely hydrogenated coconut oil with cottonseed oil (fat mixtures $A_{1}$ or $B_{1}$, groups $46,47,59$ and 60 ), to contain the same amount of linoleic acid as coconut oil, ensured, at both the $7 \%$ and $28 \%$ dietary levels, growth and efficiency constants equal to those obtained on corresponding levels of coconut oil.

Supplementation of partly or completely hydrogenated coconut oil with cottonseed oil (fat mixtures $A_{4}$ or $B_{4}$, groups $48,49,61$ and 62 ), so that the linoleic-acid content (based on isomerization analysis) was four times that of coconut oil, resulted in little better growth than that obtained on coconut oil, and not consistently different from that obtained with corresponding levels of cottonseed oil, arachis oil or maize oil (groups 50, 5I, 63, 64 and 71). 
Table 3. Number of rats and mean values for their weights, in each group after experimental periods of Io and 16 weeks, and their calorie intake and efficiency of utilization during the first 10 weeks of experiment

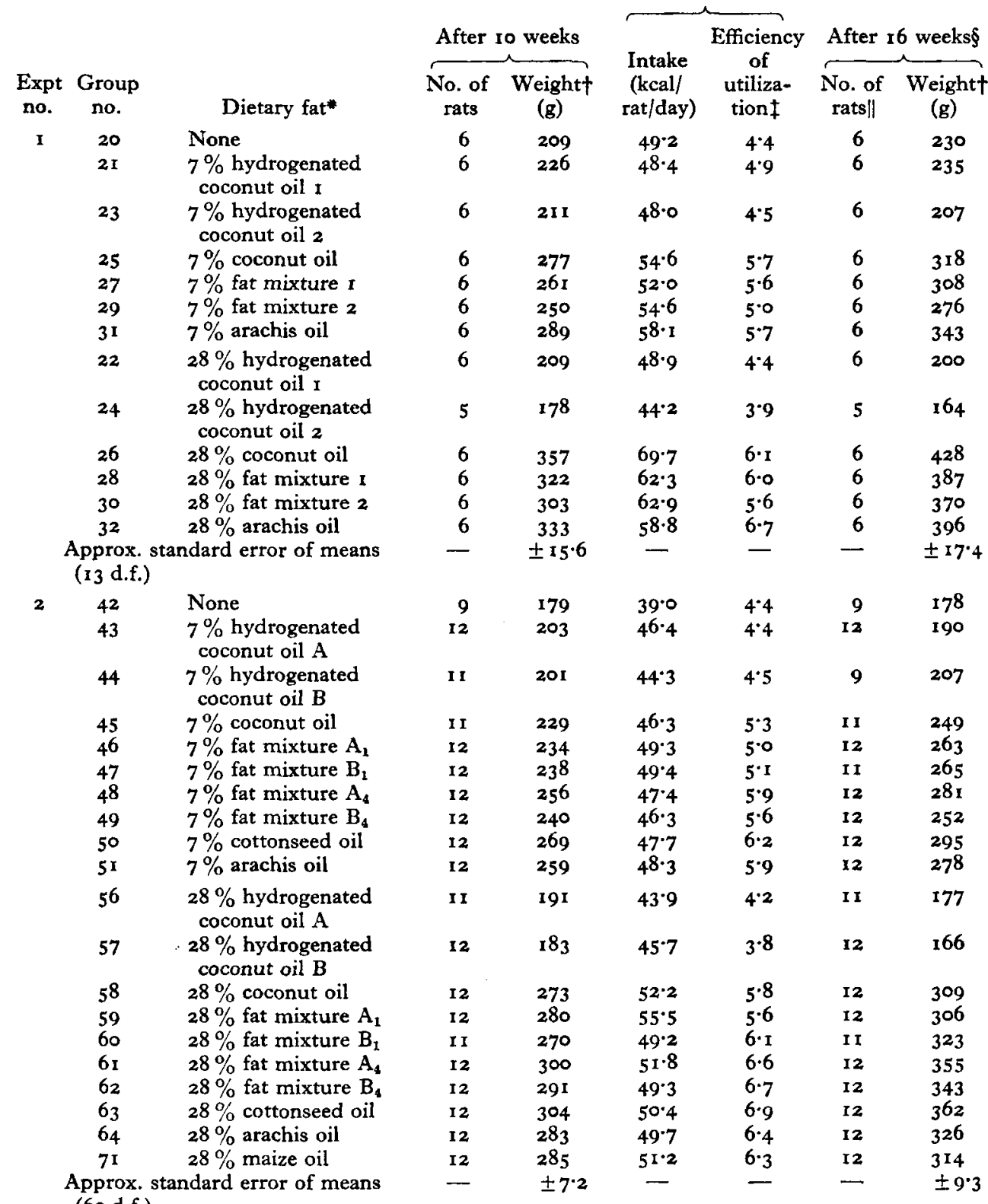

Calories rst-roth week

* Composition and chemical and physical properties of the fats used are given in Table 2.

+ In Expt $\mathrm{I}$ there were initially six rats in each group, three in each cage; mean initial weights were $58 \mathrm{~g}$. In Expt 2 there were initially twelve rats in each group, three in each cage; mean initial weights were $60 \mathrm{~g}$. The standard errors for mean weights are in both experiments based on cage means.

$\$$ (Daily gain in weight $(\mathrm{g}) /$ daily intake of calories $(\mathrm{kcal})) \times 100$.

$\S$ From the 11 th to the 16 th week about half of the rats in each group in Expt 2 were given a dietary supplement of $0.5 \%$ cholesterol and $0.5 \%$ cholic acid.

If During the experiments eleven animals died or were killed: four because of labyrinthitis and otitis media; five because of pneumonia; two died when blood was collected under ether anaesthesia for cholesterol determination. 


\section{Infrared analysis of depot fat}

From pooled samples for each group it was found that the depot fat of the rats in Expt 2, which had been fed on the diet with $28 \%$ partly or completely hydrogenated coconut oil or with coconut oil (groups 56,57 , and $5^{8}$ ), contained $3 \%$, $<\mathrm{I} \%$, and $<\mathrm{I} \%$ of trans fatty acids, respectively, calculated as elaidic acid and as percentages of total fatty acids. It will be seen from the results in Table 3 that trans fatty acids in the diet furnished by partly hydrogenated coconut oil (cf. Table 2), though laid down in depot fat, did not inhibit the growth of the rats.

\section{Clinical signs and histological findings}

The rats fed on diets without fat or with hydrogenated coconut oil as the sole dietary fat revealed the skin signs characteristic of animals reared on diets devoid of essential fatty acids. The syndrome included the presence of dandruff and scaliness of tail and legs. In several animals the tail and ventral surface of the neck became inflamed and ulcerated, and in some the tip of the tail became necrotic and fell off. Alopecia of the neck and back was also observed. At autopsy a mucopurulent or purulent otitis media, affecting one ear or both, was observed in several animals, but was not related to the amount or kind of fat given. No evidence of labyrinthitis was noted, and the otitis media had no apparent influence on the thrift of the rats.

A summary of the histopathological findings in testes, kidneys, skin and liver is presented in Table 4.

Testes. In some animals fed on the fat-free diet, or on the diets with $28 \%$ partly or completely hydrogenated coconut oil as the sole dietary fat, the number of spermia in the lumen of the seminiferous tubules of the testis was diminished, and maturation of the spermia seemed to be protracted, because the number of maturing spermia attached to Sertoli cells was increased. The rest of the seminiferous epithelium appeared normal. The epididymides were characterized by a diminished number of spermia and the presence of desquamated, degenerating spermatogenic cells. The impairment of spermatogenesis was not so advanced in this experiment lasting for I 6 weeks as in an earlier experiment of 26 weeks' duration, when the diets were devoid of essential fatty acids (Funch et al. 1957).

Kidneys. In each of the groups of Expt 2 given the diets with $28 \%$ hydrogenated coconut oil A or B (groups 56 and 57 , respectively), one rat had necrosis of the papilla. Calculi at the cortico-medullary border were noticed in some animals, but the occurrence was not correlated with the amount or type of dietary fat.

Liver. Frozen sections stained with Sudan black showed a marked accumulation of lipid in the livers of the rats fed on diets containing no fat. The storage of liver lipid was also marked in the rats receiving in the diet $7 \%$ of coconut oil or of partly (PI. I $a$ ) or completely hydrogenated coconut oil with or without supplementation with cottonseed oil, and the lipid accumulation of these animals was greater than that of animals receiving in the diet $28 \%$ of the corresponding fats $(\mathrm{Pl}$. $\mathrm{I} b, c)$. The rats fed on cottonseed oil $(\mathrm{Pl}$. I $d, e)$ or arachis oil, however, displayed the higher accumulation of liver lipid when fed on the higher amount of dietary fat. 
Table 4. Histological changes in organs or tissues of the rats after I 6 weeks on experiment

\begin{tabular}{|c|c|c|c|c|c|c|}
\hline \multirow[t]{13}{*}{$\begin{array}{c}\text { Expt } \\
\text { no. } \\
\text { I }\end{array}$} & $\begin{array}{c}\text { Group } \\
\text { no. } \\
20\end{array}$ & $\begin{array}{l}\text { Dietary fat* } \\
\text { None }\end{array}$ & $\begin{array}{l}\text { Testes, mean } \\
\text { degree of } \\
\text { degeneration } \dagger \\
0.5(0-r)\end{array}$ & $\begin{array}{c}\text { Kidneys } \ddagger \\
0\end{array}$ & $\begin{array}{c}\text { Liver, } \\
\text { mean degree } \\
\text { of lipid } \\
\text { accumulation } \$ \\
4 \cdot 2(3-5)\end{array}$ & $\begin{array}{c}\text { Epidermis, } \\
\text { no. of cell } \\
\text { layers } \\
6-8\end{array}$ \\
\hline & 21 & $\begin{array}{l}7 \% \text { hydrogenated } \\
\text { coconut oil I }\end{array}$ & o & $\circ$ & $2 \cdot 7(2-4)$ & 6-8 \\
\hline & 23 & $\begin{array}{l}7 \% \text { hydrogenated } \\
\text { coconut oil } 2\end{array}$ & 에 & 0 & $2 \cdot 2(1-3)$ & $6-8$ \\
\hline & 25 & $7 \%$ coconut oil & oll & o & $2 \cdot 5(2-3)$ & $2-3$ \\
\hline & 27 & $7 \%$ fat mixture I & $\circ$ & 0 & $2 \cdot 5(2-3)$ & $2-3$ \\
\hline & 29 & $7 \%$ fat mixture 2 & $\circ$ & $\circ$ & $2 \cdot 2(I-3)$ & $2-3$ \\
\hline & $3 \mathrm{I}$ & $7 \%$ arachis oil & oli & $\circ$ & $0.5(0-1)$ & $2-3$ \\
\hline & 22 & $\begin{array}{l}28 \% \text { hydrogenated } \\
\text { coconut oil I }\end{array}$ & $0.7 \|(0-1)$ & $\circ$ & $\circ$ & $6-8$ \\
\hline & 24 & $\begin{array}{l}28 \% \text { hydrogenated } \\
\text { coconut oil } 2\end{array}$ & $0.7(0-1)$ & $\circ$ & $0.3(0-1)$ & $6-8$ \\
\hline & 26 & $28 \%$ coconut oil & o & $\circ$ & $1 \cdot 0(0-2)$ & $2-3$ \\
\hline & 28 & $28 \%$ fat mixture 1 & o & o & $0.5(0-2)$ & $2-3$ \\
\hline & 30 & $28 \%$ fat mixture 2 & o: & $\circ$ & $0.5(0-2)$ & $2-3$ \\
\hline & 32 & $28 \%$ arachis oil & $\circ$ & $\circ$ & $1 \cdot 7(1-3)$ & $2-3$ \\
\hline \multirow[t]{22}{*}{2} & 42 & None & $0.4(0-1)$ & o & $4 \cdot 0(3-5)$ & \\
\hline & 43 & $\begin{array}{l}7 \% \text { hydrogenated } \\
\text { coconut oil A }\end{array}$ & $\begin{array}{l}0 \\
0\end{array}$ & $\stackrel{0}{0}$ & $3 \cdot 2(2-5)$ & \\
\hline & 44 & $7 \%$ hydrogenated & $\circ$ & $\circ$ & $4 \cdot 2(3-5)$ & \\
\hline & & coconut oil B & 0 & 0 & & \\
\hline & 45 & $7 \%$ coconut oil & $\circ$ & o & $3 \cdot 8(3-5)$ & \\
\hline & $4^{6}$ & $7 \%$ fat mixture $A_{1}$ & $\circ$ & ० & $3 \cdot 3(2-4)$ & \\
\hline & 47 & $7 \%$ fat mixture $B_{1}$ & $\circ$ & $\circ$ & $3 \cdot 2(2-5)$ & \\
\hline & 48 & $7 \%$ fat mixture $A_{4}$ & o & 0 & $3 \cdot 3(2-5)$ & \\
\hline & 49 & $7 \%$ fat mixture $\mathrm{B}_{4}$ & o & o & $2 \cdot 7(1-4)$ & \\
\hline & $5^{\circ}$ & $7 \%$ cottonseed oil & $\circ$ & $\circ$ & $I \cdot 2(0-2)$ & \\
\hline & $5 \mathrm{I}$ & $7 \%$ arachis oil & $\circ$ & 0 & $1 \cdot 8(1-3)$ & \\
\hline & 56 & $\begin{array}{l}28 \% \text { hydrogenated } \\
\text { coconut oil } \mathrm{A}\end{array}$ & $0.5(0-1)$ & $\begin{array}{l}\text { One rat: } \\
\text { necrosis }\end{array}$ & $I \cdot 2(0-2)$ & \\
\hline & & & & & & gated \\
\hline & 57 & $\begin{array}{l}28 \% \text { hydrogenated } \\
\text { coconut oil B }\end{array}$ & $0.5(0-1)$ & $\begin{array}{l}\text { One rat: } \\
\text { necrosis } \\
\text { of the } \\
\text { papilla }\end{array}$ & $2 \cdot 0(1-3)$ & \\
\hline & 58 & $28 \%$ coconut oil & $\circ$ & 0 & $2 \cdot 0(I-3)$ & \\
\hline & 59 & $28 \%$ fat mixture $A_{1}$ & $\circ$ & ० & $1.0(0-2)$ & \\
\hline & 60 & $28 \%$ fat mixture $B_{1}$ & $\circ$ & $\circ$ & $1 \cdot 7(1-3)$ & \\
\hline & 61 & $28 \%$ fat mixture $A_{4}$ & ० & $\circ$ & $1 \cdot 7(1-3)$ & \\
\hline & 62 & $28 \%$ fat mixture $B_{4}$ & o & ○ & $1 \cdot 7(1-3)$ & \\
\hline & 63 & $28 \%$ cottonseed oil & 에 & 0 & $2.8(2-4)$ & \\
\hline & 64 & $28 \%$ arachis oil & $\circ$ & 0 & $3 \cdot 4(3-4)$ & \\
\hline & 71 & $28 \%$ maize oil & $\circ$ & 0 & $2 \cdot 4(2-4)$ & \\
\hline
\end{tabular}

* Composition and chemical and physical properties of the fats used are given in Table 2.

$\dagger$ Assessed from a scale of o (no degeneration) to 5 (total degeneration) (see Aaes-Jørgensen, Funch, Engel \& Dam, 1956). Range of values in parentheses.

$\pm \circ$ denotes no abnormalities in papilla and cortex. Calculi at the cortico-medullary border were noticed in some animals, but the occurrence was not related to the amount or type of dietary fat.

$\S$ Assessed on a scale of o (no stainable lipid) to 5 (diffuse accumulation of lipid). Range of values in parentheses. From the 1 Ith to the 16 th week about half of the rats in each group in Expt 2 were given a dietary supplement of $0.5 \%$ cholesterol and $0.5 \%$ cholic acid. These rats had a diffuse accumulation of stainable lipid in the liver, and values for them were not included in the mean score for the groups.

II One animal displayed a severe degeneration of the seminiferous tubules. The value for it has not been included in the mean score for the group, because it probably bore no relationship to the diets eaten. 
The accumulated lipid appeared as small droplets located primarily in the perilobular region, but in some rats given cottonseed oil, arachis oil or maize oil stainable lipid appeared also around the central vein. The nuclei of the lipid-laden cells showed no pathological changes.

Deposition of lipid in the livers of fat-deficient rats has been reported by Rice \& Jackson (1933-4), Panos \& Finerty (I954) and Alfin-Slater (1957). Panos \& Finerty (1954) noticed a greater amount of lipid in the livers of male rats than in those of female, which was consistent with the higher requirement of the male for essential fatty acids.

The differences in the amounts of stainable lipid in the livers of the rats fed on dietary fats in the present experiments can apparently not be due to differences in degree of deficiency of essential fatty acids, since the amount of accumulated lipid in the liver was not lessened by substitution of coconut oil for hydrogenated coconut oil or by supplementation of the hydrogenated coconut-oil diets with cottonseed oil. This finding is in accordance with the results of an earlier experiment (Funch et al. 1957) with rats given no fat in the diet or 7 or $28 \%$ trilaurin or hydrogenated arachis oil, when the lower levels of dietary fat with or without linoleate supplementation produced the higher accumulation of liver lipid.

The liver lipids from the rats used in these experiments are being analysed to evaluate chemically their amount and to study their character.

Skin. In skin specimens from the ventral surface of the necks of the animals in Expt I a thickening of the epidermis was seen in the rats reared on fat-free diets or on diets containing partly or completely hydrogenated coconut oil as the sole dietary fat. A keratotic plugging of the opening of the hair follicles and eventual hypertrophy and degeneration of the sebaceous glands in animals deficient in essential fatty acids (Ramalingaswami \& Sinclair, 1953), which was noticed in an earlier experiment of 26 weeks' duration (Funch et al. 1957), was not seen during this shorter investigation.

\section{DISCUSSION}

It has been suggested (Aaes-Jørgensen, I954; Funch et al. 1957) that the decrease in body-weight of rats with increasing amounts of hydrogenated fat in the diet might not be explained solely by assuming that an increase in dietary fat results in an increase of the requirement for linoleic acid (Burr, 1942; Deuel, Greenberg, Anisfeld \& Melnick, I95 I). Aggravation of the effect of lack of essential fatty acids might be provoked by the presence in hydrogenated fat of isomers of the unsaturated fatty acids formed during hydrogenation. In the paper by Funch et al. (1957) it was further suggested that the difference in effect of high dietary levels of trilaurin and hydrogenated arachis oil on rats might be explained by assuming that increased amounts of long-chain dietary fatty acids increase the requirement for essential fatty acids more than do increased amounts of medium-chain acids.

Though the present results do not exclude the possibility that certain amounts of isomers of unsaturated fatty acids, isomers of linoleic acid in particular, may exert a deleterious effect on rats, they showed that partly hydrogenated coconut oil in the absence of essential fatty acids did not aggravate the deficiency syndrome more than 
did the corresponding coconut oil with which the chance of giving isomers of unsaturated fatty acids had been eliminated by complete saturation. Trans fatty acids in the diet, as furnished by partly hydrogenated coconut oil, occurred in depot fat, but did not inhibit growth. Supplementation of partly or completely hydrogenated coconut oil with cottonseed oil, so that the linoleic-acid content (based on isomerization analysis) was equal to that of unhydrogenated coconut oil, ensured rates of weight increase and thrift of the rats equal to those obtained with corresponding levels of coconut oil.

These observations are in agreement with those of Alfin-Slater, Aftergood, Bingemann, Kryder \& Deuel (1957) and of Thomasson \& Gottenbos (1957), who found that isomers of oleic acid, which constitutes the major fraction of the isomeric fatty acids in partly hydrogenated fat, did not increase the requirement for linoleate and did not in the absence of linoleate accentuate the deficiency signs. Our results are also compatible with those of Aaes-Jørgensen (1958), who found that the presence of conjugated polyenoic acids does not explain the effects on rats of hydrogenated fat in their diet.

Though it has been shown (Holman \& Aaes Jørgensen, 1956) that cis-trans- and trans-trans-isomers of linoleic acid as such cannot replace $c i s$-cis-linoleic acid in curing the signs of deficiency of essential fatty acids, these trans-isomers have not convincingly been shown to act as competitive inhibitors of essential fatty acids.

The observation that hydrogenated fat has no noxious effect provided adequate amounts of essential fatty acids are concomitantly ingested is in accord with an earlier study (Funch et al. 1957), in which $100 \mathrm{mg}$ ethyl linoleate/rat/day completely prevented the deleterious effects of hydrogenated arachis oil, and with a multigeneration study by Alfin-Slater, Wells, Aftergood \& Deuel (1957), in which the presence in hydrogenated fat of a mixture of trans-isomers and biologically active fatty acids in the ratio of about $7: 1$ ensured normal well-being of the rats, as judged by gain in weight, tibia length, reproduction, lactation, survival, and examination of tissues. The necessity of a multi-generation study in this connexion may be doubtful, since it has been shown by Johnston, Johnson \& Kummerow (1957) that trans fatty acids are not transferred from mother to young, but the studies of Alfin-Slater, Wells et al. (1957) have convincingly shown that hydrogenated fat containing adequate amounts of essential fatty acids supports normal growth, reproduction and lactation. Our results are also in agreement with those of Johnston et al. (1958) who found that trans fatty acids in the form of hydrogenated margarine stock were metabolized when fed to rats and did not inhibit growth, as well as with the extensive studies of Thomasson \& Gottenbos (1957) who observed, inter alia, that the hydrogenation process might even be favourable, since the feeding to rats of mixtures of hydrogenated fat and an oil rich in linoleic acid (i.e. sunflower-seed oil) often resulted in rates of weight increase greater than those obtained on a mixture containing the corresponding unhydrogenated oil.

The consistent observations that hydrogenated fat devoid of essential fatty acids accentuates the fat-deficiency syndrome when fed to rats as the sole dietary fat can apparently be explained by assuming: (I) that an increase in dietary fat results in an increase in their requirements for linoleic acid (Burr, 1942; Deuel et al. 195 I); (2) that 
long-chain dietary fatty acids increase their requirement for essential fatty acids more than do increased amounts of medium-chain acids (Funch et al. 1957; Thomasson \& Gottenbos, I957); (3) that saturated fatty acids increase the requirement for essential fatty acids more than do unsaturated fatty acids (Thomasson \& Gottenbos, 1957).

\section{SUMMAR Y}

I. The purpose of the experiments was to investigate the influence of increasing dietary levels of partly or completely hydrogenated coconut oil, alone or supplemented with cottonseed oil, on growth and tissue pathology of rats receiving the experimental diets for a 16 -week period, beginning at weaning. The experiments made possible comparisons between the effect of a fat in which isomers of unsaturated fatty acids formed during hydrogenation may have been present and that of a corresponding fat with which the chance of including these isomers had been eliminated by complete saturation.

2. Partly hydrogenated coconut oil did not increase the requirement for linoleic acid or, in the absence of essential fatty acids, aggravate the deficiency syndrome more than did the same amount of completely hydrogenated coconut oil. This finding indicates that isomers of unsaturated fatty acids, at any rate in small amounts as in partly hydrogenated coconut oil, have no deleterious effect on rats.

3. Trans-isomers of fatty acids in the diet, as furnished by partly hydrogenated coconut oil, occurred in depot fat, but did not inhibit growth.

4. The store of liver lipid, estimated histologically, in the rats receiving lower levels of coconut oil or hydrogenated coconut oil, alone or supplemented with cottonseed oil, was greater than that in animals receiving higher levels of the same fats. The rats given cottonseed oil or arachis oil, however, displayed the higher accumulation of liver lipid when given the higher amount of dietary fat.

5. This study, together with those of other investigators, supports the view that the biological action of hardened fats may be explained by assuming that increased levels of dietary fat increase the requirement for essential fatty acids, saturated more so than unsaturated fatty acids, long-chain more so than medium-chain acids.

\section{REFERENCES}

Aaes-Jorgensen, E. (1954). The Role of Fat in the Diet of Rats. 6. Influence on Growth of Various Fats in Ordinary Refined State and after Hydrogenation or Polymerization. Copenhagen: Store Nordiske Videnskabsboghandel.

Aaes-Jørgensen, E. (1958). F. Nutr. 66, 465 .

Aaes-Jørgensen, E., Funch, J. P., Engel, P. F. \& Dam, H. (1956). Brit. F. Nutr. 10, 292.

Alfin-Slater, R. B. (1957). F. Amer. Oil Chem. Soc. 34, 574.

Alfin-Slater, R. B., Aftergood, L., Bingemann, L., Kryder, G. D. \& Deuel, H. J. Jr. (1957). Proc. Soc. exp. Biol., N.Y., 95, $52 \mathrm{I}$.

Alfin-Slater, R. B., Wells, A. F., Aftergood, L. \& Deuel, H. J. Jr. (I957). F. Nutr. 63, 24 I.

Burr, G. O. (1942). Fed. Proc. 1, 224.

Deuel, H. J. Jr., Greenberg, S. M., Anisfeld, L. \& Melnick, D. (1951). Y. Nutr. 45, 535.

Funch, J. P., Aaes-Jørgensen, E. \& Dam, H. (1957). Brit. F. Nutr. II, 426.

Funch, J. P., Nielsen, E. \& Dam, H. (I 960). Brit. F. Nutr. 14, I.

Hammond, E. G. \& Lundberg, W. O. (1953). F. Amer. Oil Chem. Soc. 3o, 433.

Holman, R. T. \& Aaes-Jørgensen, E. (1956). Proc. Soc. exp. Biol., N. Y., 93, 175. 

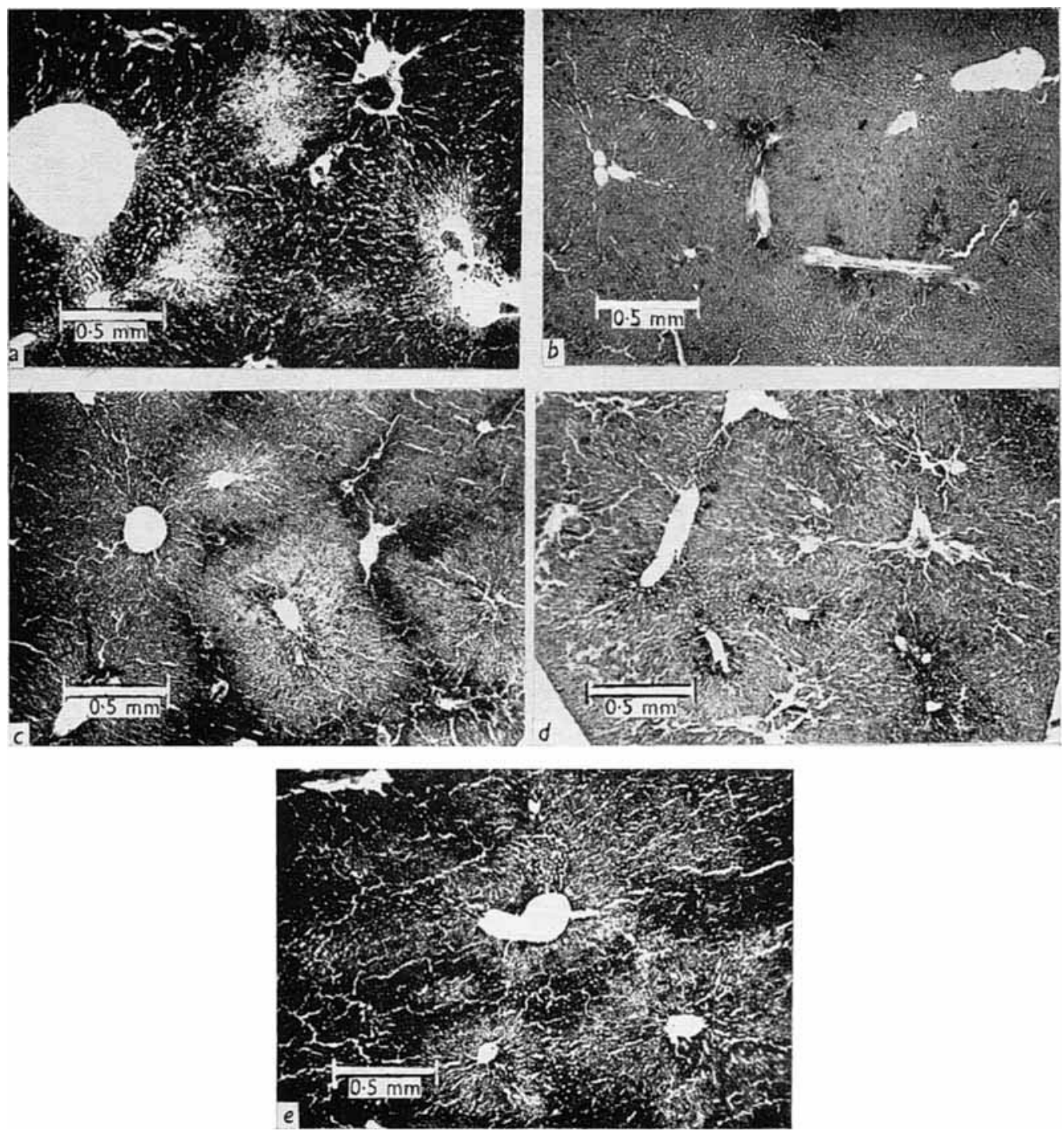
Jart, A. (1960). Acta chem. scand. (In the Press.)

Johnston, P. V., Johnson, O. C. \& Kummerow, F. A. (1957). Proc. Soc. exp. Biol., N. Y., 96, 760.

Johnston, P. V., Johnson, O. C. \& Kummerow, F. A. (1958). F. Nutr. 65, 13.

Panos, T. C. \& Finerty, J. C. (1954). F. Nutr. 54, 3 I 5.

Ramalingaswami, V. \& Sinclair, H. M. (1953). Brit. $¥$. Dermatol. 65, I.

Rice, H. G. \& Jackson, C. M. (1933-4). Proc. Soc. exp. Biol., N.Y., 31, 8 I 4.

Thomasson, H. J. \& Gottenbos, J. J. (1957). Verh. vlaam. Akad. geneesk. Belg. 19, 369-527.

\section{EXPLANATION OF PLATE}

Photomicrographs of sections of rat liver cut on a freezing microtome and stained with Sudan black. The degree of lipid accumulation is assessed on a scale of o (no stainable lipid) to 5 (diffuse accumulation of lipid).

a. Dietary fat: $7 \%$ hydrogenated coconut oil A (group 43). Degree 4. Lobuli are deeply stained for a region close to the central veins.

b. Dietary fat: $28 \%$ hydrogenated coconut oil A (group 56). Degree 1 . Slight amount of stainable lipid around the portal triads.

c. Dietary fat : $28 \%$ hydrogenated coconut oil A (group 56). Degree 2. The perilobular localization of stainable lipid is clearly seen.

d. Dietary fat: $7 \%$ cottonseed oil (group 50). Degree I. Slight amount of stainable lipid, chiefly around the central veins.

e. Dietary fat: $28 \%$ cottonseed oil (group 63 ). Degree 3 . The staining is intense in the perilobular region and in the region close to the central vein. 